\title{
Antitumor Effect of Burchellin Derivatives Against Neuroblastoma
}

\author{
MASAHIRO KURITA ${ }^{1}$, TOMOMI TAKADA ${ }^{1}$, NORIKO WAKABAYASHI ${ }^{2}$, SATORU ASAMI ${ }^{1}$, \\ SHINICHI ONO ${ }^{1}$, TAKETO UCHIYAMA ${ }^{2}$ and TAKASHI SUZUKI ${ }^{1,3}$ \\ Departments of ${ }^{1}$ Clinical Medicine, and ${ }^{2}$ Organic Chemistry, \\ School of Pharmacy, Nihon University, Funabashi, Japan; \\ ${ }^{3}$ School of Medicine, Nihon University, Itabashi, Japan
}

\begin{abstract}
Background: Neuroblastoma is one of the most commonly encountered malignant solid tumors in the pediatric age group. We examined the antitumor effects of five burchellin derivatives against human neuroblastoma cell lines. Materials and Methods: We evaluated cytotoxicity by the MTT assay for four human neuroblastoma and two normal cell lines. We also performed analysis of the apoptotic induction effect by flow cytometry, and examined the expression levels of apoptosis- and cell growth-related proteins by western blot analysis. Results: We found that one of the burchellin derivatives (compound 4) exerted cytotoxicity against the neuroblastoma cell lines. Compound 4 induced caspase-dependent apoptosis via a mitochondrial pathway. The apoptosis mechanisms induced by compound 4 involved caspase-3, -7 and -9 activation and poly (ADPribose) polymerase cleavage. In addition, compound 4 induced cell death through inhibition of the cell growth pathway (via extracellular signal-regulated kinase 1 and 2 , AKT8 virus oncogene cellular homolog, and signal transducer and activator of transcription 3). Conclusion: Compound $\mathbf{4}$ exerted cellular cytotoxicity against neuroblastoma cells via induction of caspase-dependent apoptosis, and may offer promise for further development as a useful drug for the treatment of advanced neuroblastoma.
\end{abstract}

Neuroblastoma is one of the most commonly encountered malignant solid tumors in pediatric age groups. It is an embryonal tumor derived from the neural crest, involving the

Correspondence to: Takashi Suzuki MD, Ph.D., Laboratory of Clinical Medicine, School of Pharmacy, Nihon University, 7-7-1 Narashinodai, Funabashi-shi, Chiba, 274-8555, Japan. Tel: +81 474655867, e-mail: suzuki.takashi85@nihon-u.ac.jp

Key Words: Burchellin, Lauraceae family, neuroblastoma, apoptosis, caspase, mitochondria. sympathetic nervous system and adrenal medulla. Most primary tumors occur within the abdomen, with $65 \%$ arising in the adrenal medulla (1). The International Neuroblastoma Staging System (INSS) is a surgical pathologic staging system $(1,2)$. Among patients with stage 4 disease, the reported 5-year overall survival rate is as low as $31 \%$, and still has a poor prognosis rate (3). The prognostic factors for neuroblastoma are age at diagnosis, INSS stage, tumor histopathology, myelocytomatosis oncogene cellular homolog neuroblastoma $(M Y C N)$ amplification, status and tumor DNA index, and these variables contribute to the Children's Oncology Group (COG) risk stratification $(1,2)$. Approximately $40 \%$ of all patients diagnosed as having neuroblastoma are classified into the COG high-risk group (4). Therefore, novel therapeutic strategies are urgently needed to improve the overall survival of patients with advanced neuroblastoma.

Burchellin is a neolignan found in plants belonging to the Lauraceae family, such as Aniba burchellii (5-7) and Ocotea cymbarum (8). However, there are few reports on the bioactivity of burchellin (9). The present study is, to our knowledge, the first to investigate the antitumor effect of this compound against human cancer cell lines. We previously reported the antitumor effects of neolignans similar in structure to burchellin, against cancer cell lines such as human leukemia cell lines (10) and human neuroblastoma cell lines (11). In this study, we examined the cytotoxicity of burchellin derivatives and investigated the important mechanisms underlying the antitumor effect of these compounds on neuroblastoma cells.

\section{Materials and Methods}

General procedure for syntheses of burchellin (2) and its analogs (3-5) (Figure 1). Enol (1) and ( \pm )-burchellin (2) were prepared according to the procedure by Engler et al. (12). Alkyl iodide (3.0 $\mathrm{mmol})$ was added to a mixture of enol $(50 \mathrm{mg}, 0.15 \mathrm{mmol})$ and $\mathrm{K}_{2} \mathrm{CO}_{3}(207 \mathrm{mg}, 1.50 \mathrm{mmol})$ in acetone $(10 \mathrm{ml})$, and the mixture 
<smiles>C=CC[C@]12C=C(O)C(=O)C=C1O[C@@H](c1ccc3c(c1)OCO3)[C@@H]2C</smiles>

1a)<smiles>[R]OC1=C[C@]2(CC=C)C(=CC1=O)O[C@@H](c1ccc3c(c1)OCO3)[C@H]2C</smiles>

2-5

\section{R: - $-\mathrm{CH}_{3}$ (2, burchellin), $-\mathrm{CH}_{2} \mathrm{CH}=\mathrm{CH}_{2}(3),-\left(\mathrm{CH}_{2}\right)_{4} \mathrm{CH}_{3}(4)-\left(\mathrm{CH}_{2}\right)_{7} \mathrm{CH}_{3}$ (5)}

Figure 1. Preparation of burchellin (2) and its analogs (3-5).

was stirred at room temperature for $20 \mathrm{~h}$. The inorganic salts were removed by filtration, and the filtrate was concentrated. Chromatography of the residue with $20 \%$ EtOAc in hexane as an eluent gave corresponding enol ether (3-5) as white solid.

Data for compound $3\left(\mathrm{R}=-\mathrm{CH}_{2} \mathrm{CH}=\mathrm{CH}_{2}\right)$ : HRESIMS $\mathrm{m} / \mathrm{z}$ $389.1365[\mathrm{M}+\mathrm{Na}]^{+}$(calcd for $\mathrm{C}_{22} \mathrm{H}_{22} \mathrm{O}_{5} \mathrm{Na}, 389.1365$ ); ${ }^{1} \mathrm{H}-\mathrm{NMR}$ $\left(600 \mathrm{MHz}, \mathrm{CDCl}_{3}\right) ; 6.80\left({ }^{1} \mathrm{H}, \mathrm{d}, J=7.5 \mathrm{~Hz}\right.$, aromatic- $\left.\mathrm{H}\right), 6.77\left({ }^{1} \mathrm{H}\right.$, $\mathrm{dd}, J=7.5,2.0 \mathrm{~Hz}$, aromatic-H), $6.76\left({ }^{1} \mathrm{H}\right.$, br s, aromatic- $\left.\mathrm{H}\right), 6.01\left({ }^{1} \mathrm{H}\right.$, $\left.\mathrm{m},-\mathrm{C} \underline{\mathrm{H}}=\mathrm{CH}_{2}\right), 5.98\left(2 \mathrm{H}, \mathrm{s},-\mathrm{OC}_{2} \mathrm{O}-\right), 5.80\left({ }^{1} \mathrm{H}, \mathrm{s},-\mathrm{C}=\mathrm{CHC}(=\mathrm{O})-\right)$, $5.53\left({ }^{1} \mathrm{H}, \mathrm{m},-\mathrm{CH}_{2} \mathrm{C} \underline{\mathrm{H}}=\mathrm{CH}_{2}\right), 5.44\left({ }^{1} \mathrm{H}, \mathrm{s},-\mathrm{CC} \underline{\mathrm{H}}=\mathrm{C}-\mathrm{O}-\right), 5.37\left({ }^{1} \mathrm{H}, \mathrm{dd}\right.$, $\left.J=17.0,1.0 \mathrm{~Hz},-\mathrm{CH}=\mathrm{CH}_{2 \mathrm{a}}\right), 5.28\left({ }^{1} \mathrm{H}, \mathrm{dd}, J=10.0,1.0 \mathrm{~Hz},-\mathrm{CH}=\mathrm{CH}_{2 \mathrm{~b}}\right)$, $5.16\left({ }^{1} \mathrm{H}, \mathrm{d}, J=10.0 \mathrm{~Hz}\right.$, phenyl-CHO- $), 5.08\left({ }^{1} \mathrm{H}, \mathrm{dd}, J=11.0,1.0 \mathrm{~Hz}\right.$, $\left.-\mathrm{CH}=\mathrm{C}_{2 \mathrm{a}}{ }^{\prime}\right), 5.00\left({ }^{1} \mathrm{H}, \mathrm{dd}, J=17.0,1.0 \mathrm{~Hz},-\mathrm{CH}=\mathrm{C}_{2 \mathrm{~b}}{ }^{\prime}\right), 4.40(2 \mathrm{H}$, $\left.\mathrm{dd}, J=5.5,2.0 \mathrm{~Hz},-\mathrm{OC}_{2} \mathrm{CHC}=\mathrm{CH}_{2}\right), 2.53,2.32\left(\right.$ each ${ }^{1} \mathrm{H}, \mathrm{dd}$, $\left.J=13.5,7.5 \mathrm{~Hz},-\mathrm{CC} \underline{H}_{2} \mathrm{CHC}=\mathrm{CH}_{2}\right), 2.25\left({ }^{1} \mathrm{H}, \mathrm{dq}, J=10.0,7.0 \mathrm{~Hz},-\right.$ $\left.\mathrm{C}^{\mathrm{HCH}} \mathrm{H}_{3}\right), 1.83-1.41\left(6 \mathrm{H}, \mathrm{m},-\mathrm{OCH}_{2}\left(\mathrm{C}_{2}\right)_{3} \mathrm{CH}_{3}\right), 1.13\left({ }^{3} \mathrm{H}, \mathrm{d}, J=7.0\right.$ $\left.\mathrm{Hz},-\mathrm{CHC}_{\underline{3}}\right), 0.92\left(3 \mathrm{H}, \mathrm{t}, J=7.0 \mathrm{~Hz},-\mathrm{CH}_{2} \underline{\mathrm{C}}_{\underline{3}}\right) ;{ }^{13} \mathrm{C}-\mathrm{NMR}(125$ $\left.\mathrm{MHz}, \mathrm{CDCl}_{3}\right)$; 183.1(C), 182.8(C), 152.2(C), 148.3(C), 148.2(C), 132.6(C), $\quad 131.6(\mathrm{CH}), \quad 130.9(\mathrm{CH}), \quad 120.6(\mathrm{CH}), \quad 120.1\left(\mathrm{CH}_{2}\right)$, $118.1\left(\mathrm{CH}_{2}\right), \quad 109.6(\mathrm{CH}), \quad 108.3(\mathrm{CH}), \quad 106.6(\mathrm{CH}), \quad 102.3(\mathrm{CH})$, 101.5( $\left(\mathrm{CH}_{2}\right), 91.0(\mathrm{CH}), 69.1\left(\mathrm{CH}_{2}\right), 51.1(\mathrm{C}), 49.7(\mathrm{CH}), 36.7\left(\mathrm{CH}_{2}\right)$, $8.4\left(\mathrm{CH}_{3}\right)$

Data for compound $4\left(\mathrm{R}=-\left(\mathrm{CH}_{2}\right)_{4} \mathrm{CH}_{3}\right)$ : HRESIMS $\mathrm{m} / z, 419.1834$ $[\mathrm{M}+\mathrm{Na}]^{+}$(calcd for $\left.\mathrm{C}_{24} \mathrm{H}_{28} \mathrm{O}_{5} \mathrm{Na}, 419.1834\right) ;{ }^{1} \mathrm{H}-\mathrm{NMR}(600 \mathrm{MHz}$, $\mathrm{CDCl} 3)$; 6.81-6.76 (3H, aromatic- $\mathrm{H}), 5.98\left({ }^{2} \mathrm{H}, \mathrm{s},-\mathrm{OCH}_{2} \mathrm{O}-\right), 5.79$ $\left({ }^{1} \mathrm{H}, \mathrm{s},-\mathrm{C}=\mathrm{CHC}(=\mathrm{O})-\right), 5.55\left({ }^{1} \mathrm{H}, \mathrm{m},-\mathrm{CH}_{2} \mathrm{CH}=\mathrm{CH}_{2}\right), 5.40\left({ }^{1} \mathrm{H}, \mathrm{s},-\right.$ $\mathrm{CC} \underline{\mathrm{H}}=\mathrm{C}-\mathrm{O}-), 5.15\left({ }^{1} \mathrm{H}, \mathrm{d}, J=10.0 \mathrm{~Hz}\right.$, phenyl-C $\left.\underline{\mathrm{H}}-\mathrm{O}-\right), 5.08\left({ }^{1} \mathrm{H}, \mathrm{dd}\right.$, $\left.J=10.5,1.5 \mathrm{~Hz},-\mathrm{CH}=\underline{\mathrm{C}}_{2 \mathrm{a}}\right), 5.00\left({ }^{1} \mathrm{H}, \mathrm{dd}, J=16.5,1.5 \mathrm{~Hz},-\right.$ $\left.\mathrm{CH}=\mathrm{C}_{2 \mathrm{~b}}\right), 3.74\left(2 \mathrm{H}, \mathrm{m},-\mathrm{OC}_{2} \underline{\mathrm{CH}}_{2^{-}}\right), 2.53,2.42\left(\right.$ each ${ }^{1} \mathrm{H}, \mathrm{dd}$, $\left.J=14.0,7.0 \mathrm{~Hz},-\mathrm{CCH}_{2} \mathrm{CHC}=\mathrm{CH}_{2}\right), 2.26\left({ }^{1} \mathrm{H}, \mathrm{dq}, J=10.0,7.0 \mathrm{~Hz},-\right.$ $\left.\mathrm{C}^{\mathrm{HCH}} \mathrm{H}_{3}\right), 1.83-1.41\left(6 \mathrm{H}, \mathrm{m},-\mathrm{OC}_{2}{ }_{2}\left(\mathrm{CH}_{2}\right)_{3} \mathrm{CH}_{3}\right), 1.13\left({ }^{3} \mathrm{H}, \mathrm{d}, J=7.0\right.$ $\left.\mathrm{Hz},-\mathrm{CHC}_{3}\right), 0.92\left({ }^{3} \mathrm{H}, \mathrm{d}, J=7.0 \mathrm{~Hz},-\mathrm{CH}_{2} \underline{\mathrm{C}}_{3}\right) ;{ }^{3} \mathrm{C}-\mathrm{NMR}(125$ $\left.\mathrm{MHz}, \mathrm{CDCl}_{3}\right) ; 182.9(\mathrm{C}), 181.0(\mathrm{C}), 152.9(\mathrm{C}), 148.3(\mathrm{C}), 148.2(\mathrm{C})$,

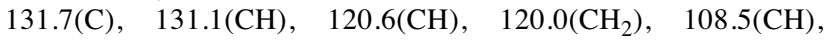
108.2(CH), $106.6(\mathrm{CH}), \quad 102.3(\mathrm{CH}), \quad 101.4\left(\mathrm{CH}_{2}\right), \quad 91.0(\mathrm{CH})$, 68.3( $\left(\mathrm{CH}_{2}\right), 51.0(\mathrm{C}), 49.7(\mathrm{CH}), 36.7\left(\mathrm{CH}_{2}\right), 28.3\left(\mathrm{CH}_{2}\right), 28.1\left(\mathrm{CH}_{2}\right)$, $22.4\left(\mathrm{CH}_{2}\right), 14.0\left(\mathrm{CH}_{3}\right), 8.4\left(\mathrm{CH}_{3}\right)$

Data for compound $5\left(\mathrm{R}=-\left(\mathrm{CH}_{2}\right)_{7} \mathrm{CH}_{3}\right)$ : HRESIMS $\mathrm{m} / z, 461.2304$ $[\mathrm{M}+\mathrm{Na}]^{+}$(calcd for $\left.\mathrm{C}_{27} \mathrm{H}_{34} \mathrm{O}_{5} \mathrm{Na}, 461.2304\right) .{ }^{1} \mathrm{H}-\mathrm{NMR}(600 \mathrm{MHz}$, $\left.\mathrm{CDCl}_{3}\right)$; 6.81-6.76 ( ${ }^{3} \mathrm{H}$, aromatic- $\left.\mathrm{H}\right), 5.98\left({ }^{2} \mathrm{H}, \mathrm{s},-\mathrm{OC} \underline{\mathrm{H}}_{2} \mathrm{O}-\right), 5.79\left({ }^{1} \mathrm{H}\right.$, $\mathrm{s},-\mathrm{C}=\mathrm{CHC}(=\mathrm{O})-), 5.55\left({ }^{1} \mathrm{H}, \mathrm{m},-\mathrm{CH}_{2} \mathrm{C} \underline{\mathrm{H}}=\mathrm{CH}_{2}\right), 5.40\left({ }^{1} \mathrm{H}, \mathrm{s},-\mathrm{CC} \underline{\mathrm{H}}=\mathrm{C}-\right.$ O-), $5.15\left({ }^{1} \mathrm{H}, \mathrm{d}, J=10.0 \mathrm{~Hz}\right.$, phenyl-C $\left.\underline{\mathrm{H}}-\mathrm{O}-\right), 5.08\left({ }^{1} \mathrm{H}, \mathrm{dd}, J=10.5\right.$, $\left.1.5 \mathrm{~Hz},-\mathrm{CH}=\underline{\mathrm{CH}}_{2 \mathrm{a}}\right), 5.00\left({ }^{1} \mathrm{H}, \mathrm{dd}, J=16.5,1.5 \mathrm{~Hz},-\mathrm{CH}=\underline{\mathrm{C}}_{2 \underline{\mathrm{b}}}\right), 3.74$ $\left({ }^{2} \mathrm{H}, \mathrm{m},-\mathrm{OCH}_{2} \mathrm{C}_{\underline{2}^{-}}\right.$), 2.53, 2.32 (each ${ }^{1} \mathrm{H}, \mathrm{dd}, J=13.0,7.0 \mathrm{~Hz},-$ $\left.\mathrm{CCH}_{2} \mathrm{CHC}=\mathrm{CH}_{2}\right), 2.26\left({ }^{1} \mathrm{H}, \mathrm{dq}, J=10.0,7.0 \mathrm{~Hz},-\mathrm{CHCH}_{3}\right), 1.82-$ $1.27\left(12 \mathrm{H}, \mathrm{m},-\mathrm{OCH}_{2}\left(\mathrm{C}_{2}\right) 6 \mathrm{CH}_{3}\right), 1.13\left({ }^{3} \mathrm{H}, \mathrm{d}, J=7.0 \mathrm{~Hz},-\mathrm{CHCH}_{3}\right)$, $0.88\left({ }^{3} \mathrm{H}, \mathrm{d}, J=7.0 \mathrm{~Hz},-\mathrm{CH}_{2} \mathrm{CH}_{3}\right) ;{ }^{13} \mathrm{C}-\mathrm{NMR}\left(125 \mathrm{MHz}, \mathrm{CDCl}_{3}\right)$; $182.9(\mathrm{C}), \quad 181.0(\mathrm{C}), \quad 152.9(\mathrm{C}), 148.3(\mathrm{C}), \quad 148.2(\mathrm{C}), \quad 131.7(\mathrm{C})$, $131.1(\mathrm{CH}), \quad 120.6(\mathrm{CH}), \quad 120.0\left(\mathrm{CH}_{2}\right), \quad 108.5(\mathrm{CH}), \quad 108.2(\mathrm{CH})$, 106.6(CH), 102.3(CH), 101.4( $\left(\mathrm{CH}_{2}\right), 91.0(\mathrm{CH}), 68.3\left(\mathrm{CH}_{2}\right), 51.0(\mathrm{C})$, 49.7(CH), 36.7 $\left(\mathrm{CH}_{2}\right), 31.8\left(\mathrm{CH}_{2}\right), 29.3\left(\mathrm{CH}_{2}\right), 29.1\left(\mathrm{CH}_{2}\right), 28.6\left(\mathrm{CH}_{2}\right)$, 26.0 $\left(\mathrm{CH}_{2}\right), 22.7\left(\mathrm{CH}_{2}\right), 14.1\left(\mathrm{CH}_{3}\right), 8.4\left(\mathrm{CH}_{3}\right)$

Materials and reagents. The chemical structure of burchellin derivatives are shown in Figure 1. They were prepared in Dr. Uchiyama's laboratory. A stock solution of each compound of 50 $\mathrm{mM}$ was prepared in dimethyl sulfoxide (DMSO, Sigma-Aldrich, MO, USA), stored at $-20^{\circ} \mathrm{C}$ and then diluted as needed in the cell culture medium. 3-[4,5-Dimethylthiazol-2-yl]-2,5-diphenyltetrazoliun bromide (MTT) and Hoechst 33342 were purchased from Sigma-Aldrich. The pan-caspase inhibitor benzyloxycarbonyl-ValAla-Asp(OMe)-fluoromethylketone (z-VAD-fmk) was purchased from Medical Biological Laboratories (Nagoya, Japan). Alexia Fluor ${ }^{\circledR} 488$ annexin V/Dead Cell apoptosis kit was purchased from Life Technologies Invitrogen (CA, USA)

Cell lines and culture conditions. Human neuroblastoma cell lines (IMR-32, LA-N-1, and SK-N-SH provided by RIKEN Cell Bank; and NB-39 kindly provided by Dr. Toshimitsu Suzuki, Fukushima Medical University) were maintained in RPMI-1640 medium (Life Technologies Invitrogen) supplemented with $10 \%$ fetal bovine serum (FBS) (Thermo Scientific HyClone, UT, USA) at $37^{\circ} \mathrm{C}$ in a humidified incubator in an atmosphere with $95 \%$ air $/ 5 \% \mathrm{CO}_{2}$. Normal human dermal fibroblasts (NHDF) and human umbilical vein endothelial cells (HUVECs), obtained from Lonza Japan (Tokyo, Japan), were cultured in FGM-2 (Lonza Japan) and EGM-2 (Lonza Japan), respectively, under the same andirons described above.

Viability assay (MTT). Neuroblastoma cell lines $\left(1 \times 10^{4}\right.$ cells/well) were prepared in a 96-well culture plate and incubated for $24 \mathrm{~h}$. The cells were then treated with burchellin derivatives (final concentration: 1, 3, 10, 30, and $100 \mu \mathrm{M}$ ) or DMSO as vehicle control for $48 \mathrm{~h}$. Then, $0.5 \%$ MTT solution was added to the well at $10 \%$ of the volume of the medium, and incubation was continued for $3 \mathrm{~h}$ at $37^{\circ} \mathrm{C} / 5 \% \mathrm{CO}_{2}$. A stop solution $(0.04 \mathrm{~N} \mathrm{HCl}$ in isopropanol) was added at a volume of $100 \mu \mathrm{l}$ to the culture 
1

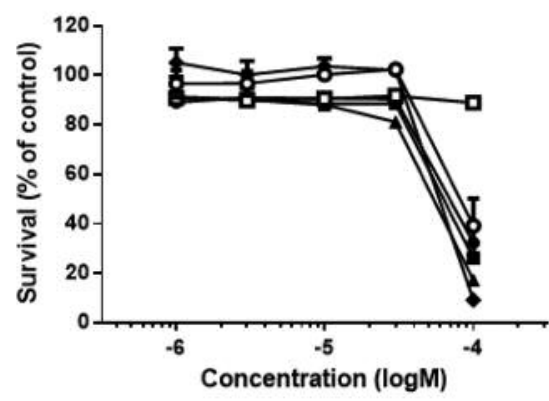

4

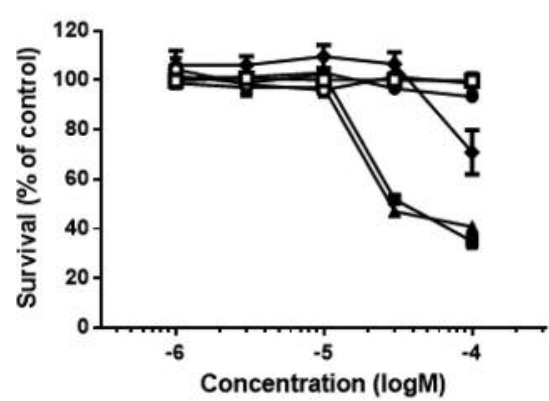

2

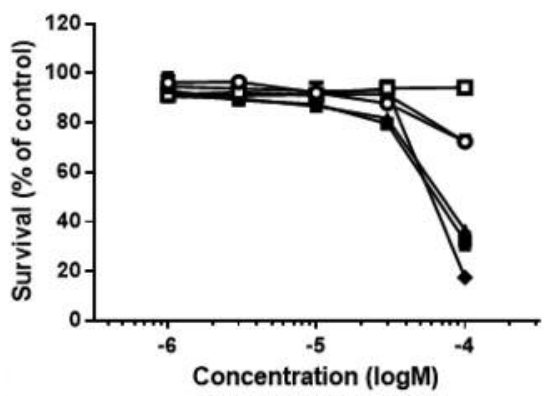

5

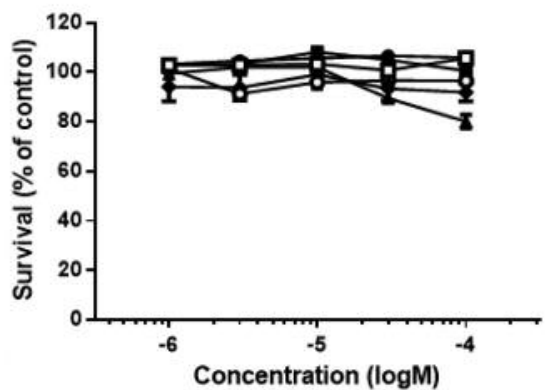

3
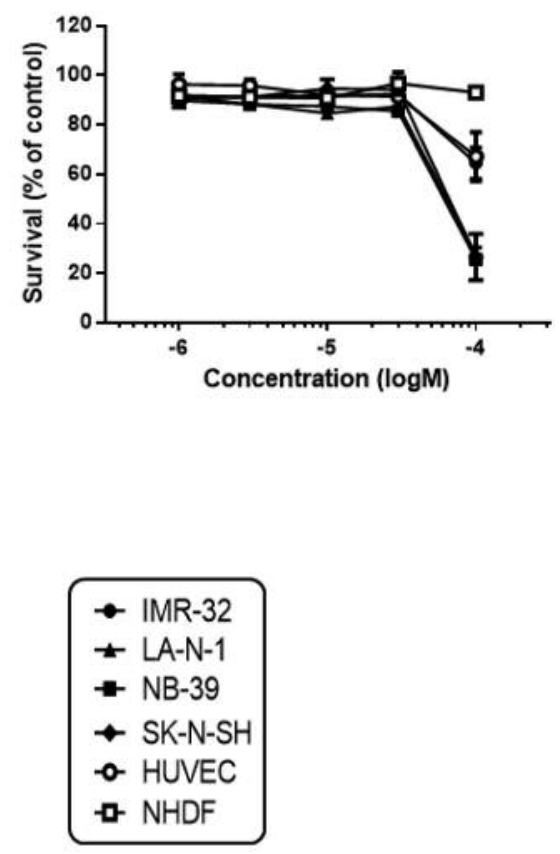

Figure 2. Cytotoxicity of burchellin derivatives against four neuroblastoma and two normal cell lines. Cytotoxicity was determined by the MTT assay. The cells were treated with burchellin derivatives $\left(1 \times 10^{-6}-1 \times 10^{-4} \mathrm{M}\right)$ for $48 \mathrm{~h}$ and the relative the cell survival compared to that in the vehicle control was calculated. Data are expressed as means $\pm \operatorname{SEM}(n=3)$.

medium in each well, and the absorbance was measured at 570 $\mathrm{nm}$ (test) and $655 \mathrm{~nm}$ (reference), after thorough pipetting to disperse the generated blue formazan. The cell survival rate was calculated as a percentage that of treated group versus that of the vehicle-control group. The normal cells $\left(2 \times 10^{4}\right.$ cells/well $)$ were plated onto the respective culture media, and the assay was performed as described above. The experiments were repeated in triplicate.

Viability assay after addition of a caspase inhibitor (z-VAD-fmk). NB-39 cells $\left(1 \times 10^{4}\right.$ cells/well) and z-VAD-fmk (final concentration $40 \mu \mathrm{M})$ were mixed in a 96-well culture plate and incubated for 24 $\mathrm{h}$. Then, the cells were treated with compound 4 (final concentration: $100 \mu \mathrm{M})$, cisplatin $(10 \mu \mathrm{M}$ as a positive control) or DMSO as vehicle control for $48 \mathrm{~h}$. An MTT assay was performed as described above. The experiments were repeated in triplicate.

Hoechst 33342 staining. Apoptotic nuclear morphology was observed by staining with Hoechst 33342 . NB-39 cells $\left(1 \times 10^{5}\right.$ cells/well) were plated onto the wells of a 6-well culture plate and incubated for $24 \mathrm{~h}$. They were then treated with burchellin derivatives (final concentrations: $1,10,30$, and $100 \mu \mathrm{M}$ ), cisplatin (10 $\mu \mathrm{M}$ as a positive control) or a vehicle control for $48 \mathrm{~h}$, and Hoechst 33342 solution (final concentration: $0.001 \%$ of the medium) was added to the wells. The wells were allowed to stand for $15 \mathrm{~min}$ and then morphological changes were examined under a fluorescence microscope (IX-71, Olympus, Tokyo, Japan). The experiments were repeated in triplicate.

Annexin V-propidium iodide (PI) double staining analysis (flow cytometry). Early apoptosis was detected using the Alexia Fluor ${ }^{\circledR} 488$ annexin V/Dead Cell apoptosis kit. NB-39 cells $\left(1 \times 10^{6}\right.$ cells/well $)$ were plated onto the wells of a 6-well culture plate and incubated for $24 \mathrm{~h}$. They were then treated with burchellin derivatives (final concentrations: 10,30 , and $100 \mu \mathrm{M}$ ) or a vehicle control for $24 \mathrm{~h}$. The cells were then collected and washed with ice-cold PBS and centrifuged after stirring, and the supernatant was discarded. The cell sediments were washed with annexin-binding buffer and stained with annexin V-Alexa Fluor ${ }^{\circledR} 488$ and PI for 15 min. The cell samples were analyzed by flow cytometry using a FC500 flow cytometer (Beckman Coulter, CA, USA) in the FL1 and FL4 ranges.

Preparation of subcellular fractions and western blotting. Wholecell proteins were obtained in an extraction buffer. NB-39 cells $\left(2 \times 10^{6}\right.$ cells/dish $)$ were plated onto $60-\mathrm{mm}$ culture dishes and incubated for $24 \mathrm{~h}$. The cells were then treated with burchellin derivatives (final concentration: $30 \mu \mathrm{M})$ for $0-48 \mathrm{~h}(0 \mathrm{~h}$ refers to untreated dishes). They were then collected and washed with icecold Tris-buffered saline (TBS) and lysed in an extraction buffer. The cells were disrupted by sonication twice for $30 \mathrm{~s}$ each, and centrifuged at $20,630 \times g$ for $10 \mathrm{~min}$ at $0^{\circ} \mathrm{C}$. Protein concentrations in the cell supernatants were determined using a Protein Assay 
Normal
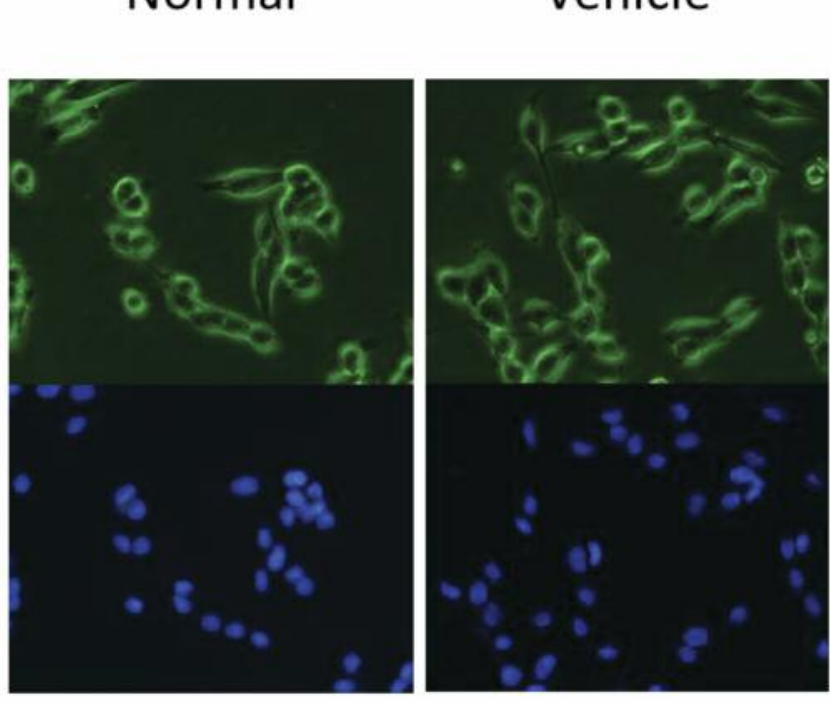

Vehicle
Cisplatin
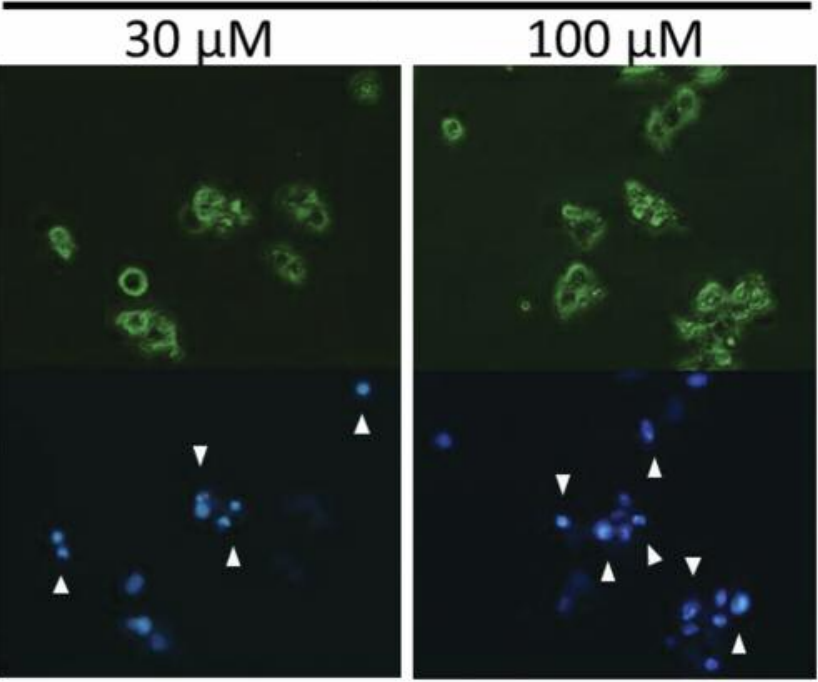

Compound 4
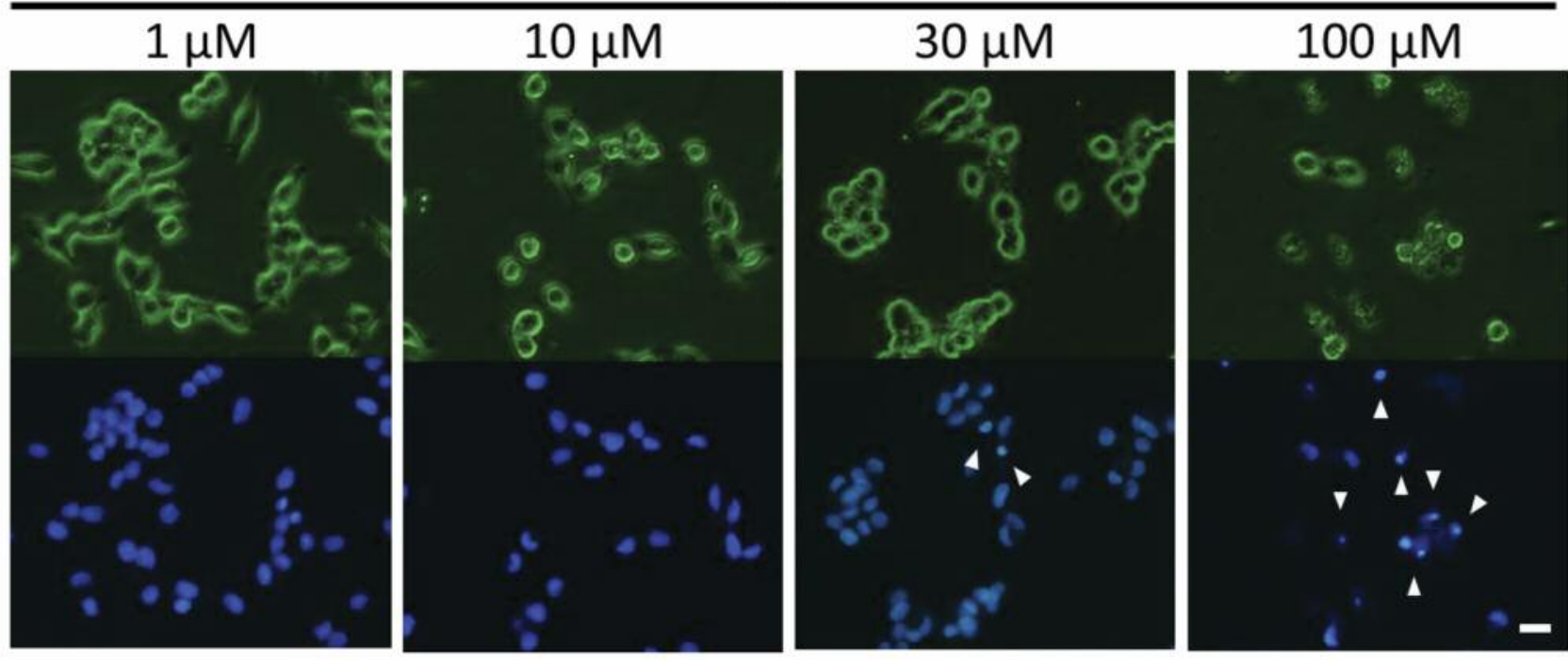

Figure 3. Morphological observation by Hoechst 33342 staining. NB-39 cells were treated with compound 4 (1, 10, 30, 100 $\mu$ M), cisplatin (30, $100 \mu \mathrm{M}$ as a positive control) or dimethylsulfoxide (as a vehicle control) for $24 \mathrm{~h}$. Phase-contrast images (upper) and fluorescence images (lower) were obtained. Arrows at 30 and $100 \mu \mathrm{M}$ indicate the morphological features of apoptosis, including cell shrinkage, nuclear condensation, and nuclear fragmentation. Scale bar: $20 \mu \mathrm{m}$.

Rapid Kit (Wako Pure Chemical Industries), using BSA as a reference. The subcellular fractions, as loading samples containing $10 \mu \mathrm{g}$ of the proteins, were separated by sodium dodecyl sulfatepolyacrylamide gel electrophoresis (SDS-PAGE) and transferred onto polyvinylidene difluoride membranes (Merck Millipore, Darmstadt, Germany). After blocking with 5\% skim milk or $3 \%$ BSA for $1 \mathrm{~h}$ at room temperature, the membranes were probed with the primary antibodies overnight at $4^{\circ} \mathrm{C}$. After another wash, the membranes were incubated with horseradish peroxidase-conjugated secondary antibodies for $1 \mathrm{~h}$ at room temperature. The blots were examined using an ECL system (GE Healthcare) and imaged using a LAS-1000 plus luminescent image analyzer (FUJIFILM, Tokyo, Japan). The densities of the bands were analyzed using NIH ImageJ software (U.S. National Institutes of Health, Bethesda, MD, USA). The primary antibodies used were as follows: anti-caspase-3, anticleaved caspase-3, anti-caspase-7, anti-caspase-9, anti-B-cell lymphoma 2 protein (BCL-2), anti-BCL-2-associated $\mathrm{X}$ protein (BAX), anti-apoptosis-inducing factor (AIF), anti-survivin, anti-X- 


\section{Compound 4}

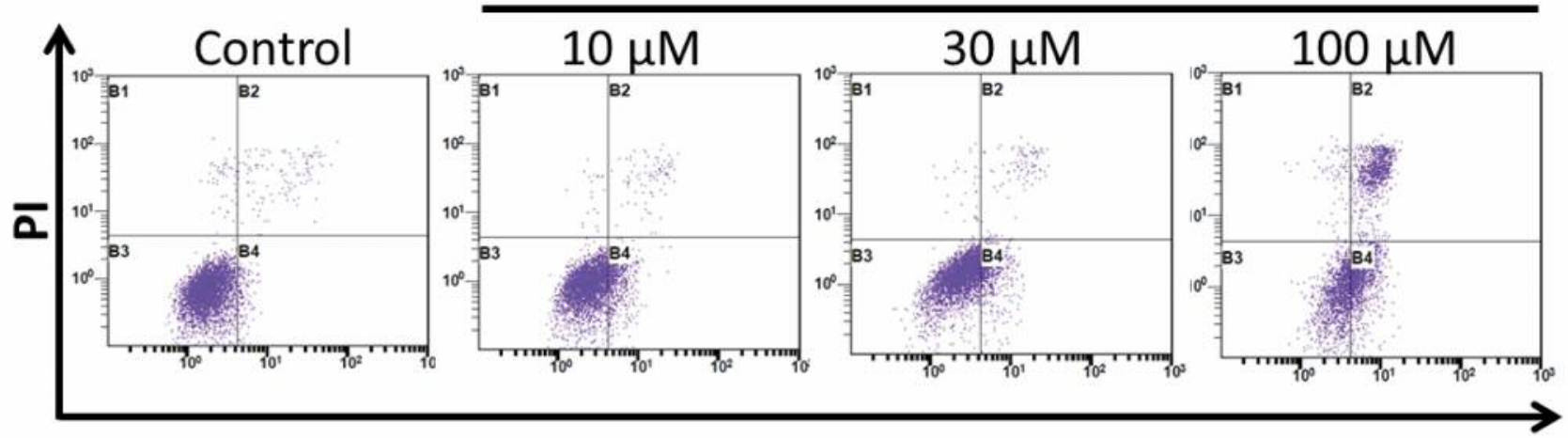

\section{Annexin V}

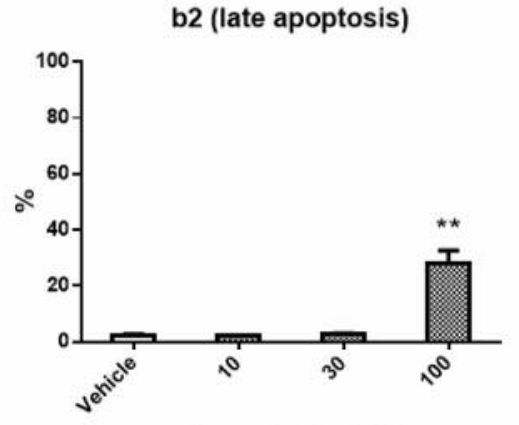

Concentration $(\mu \mathrm{M})$

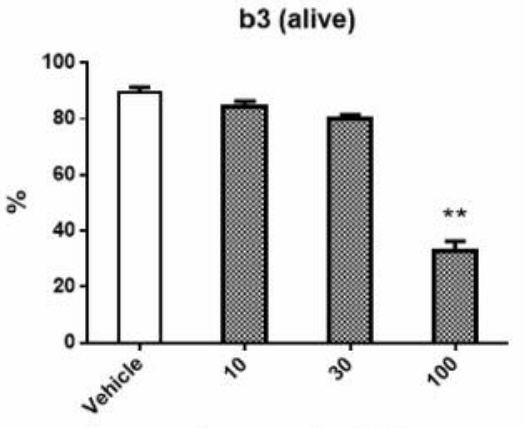

Concentration $(\mu \mathrm{M})$ b4 (early apoptosis)

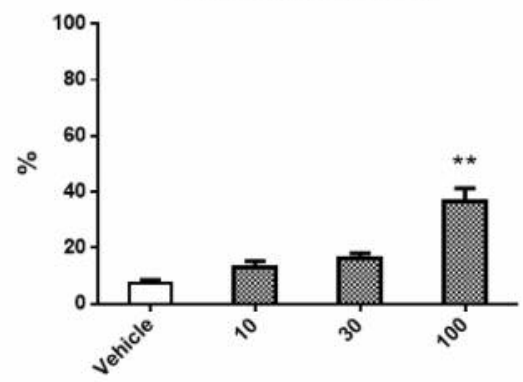

Concentration $(\mu \mathrm{M})$

Figure 4. Analysis of early apoptotic cells by flow cytometry. NB-39 cells were treated with compound 4 (10, 30 , 100 $\mu$ M) or dimethylsulfoxide (as a vehicle control) for $24 \mathrm{~h}$. A: B2: late apoptotic and necrotic cells; B3: viable cells; B4: early apoptotic cells. B: Percentages of the cell populations in each phase shown in (A). Significantly different at *p<0.05,**p<0.01 versus vehicle control. PI: Propidium iodide.

linked inhibitor of apoptosis protein (XIAP), anti-extracellular signal-regulated kinase 1 and 2 (ERK1/2), anti-phospho-ERK1/2, anti-AKT8 virus oncogene cellular homolog (AKT), anti-phosphoAKT, anti-signal transducer and activator of transcription 3 (STAT3), anti-phospho-STAT3 (Cell Signaling Technology, Danvers, MA, USA), anti-poly (ADP-ribose) polymerase (PARP), anti-second mitochondria-derived activator of caspase/direct IAPbinding protein with low PI (SMAC/DIABLO) (BD Biosciences, San Jose, CA, USA), and anti- $\beta$-tubulin (Sigma-Aldrich).

Statistical analysis. Data are expressed as means \pm SEM $(n=3)$. Significance testing was performed by one-way analysis of variance (ANOVA) followed by Bonferroni's test for comparing three or more data.

\section{Results}

We investigated the cytotoxicity of burchellin derivatives (Figure 1) against four neuroblastoma cell lines and two normal cells by the MTT assay. Compound $\mathbf{4}$ was found to exert cytotoxicity against two of the neuroblastoma cell

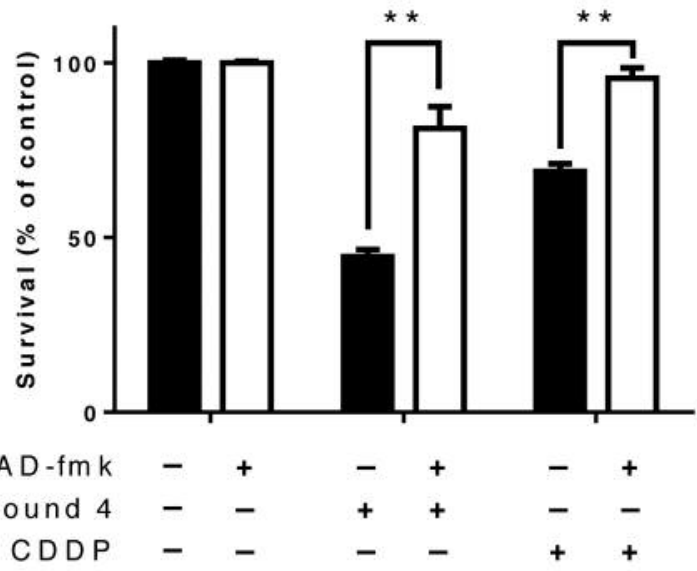

Figure 5. Caspase inhibitor assay (z-VAD-fmk). NB-39 cells were treated with the pan-caspase inhibitor z-VAD-fmk $(40 \mu M)$, compound $4(100 \mu M)$, cisplatin $(10 \mu \mathrm{M}$ as a positive control) or dimethylsulfoxide (as a vehicle control) for $48 \mathrm{~h}$. Significantly different at $* p<0.05$, $* * p<0.01$ versus vehicle control. 


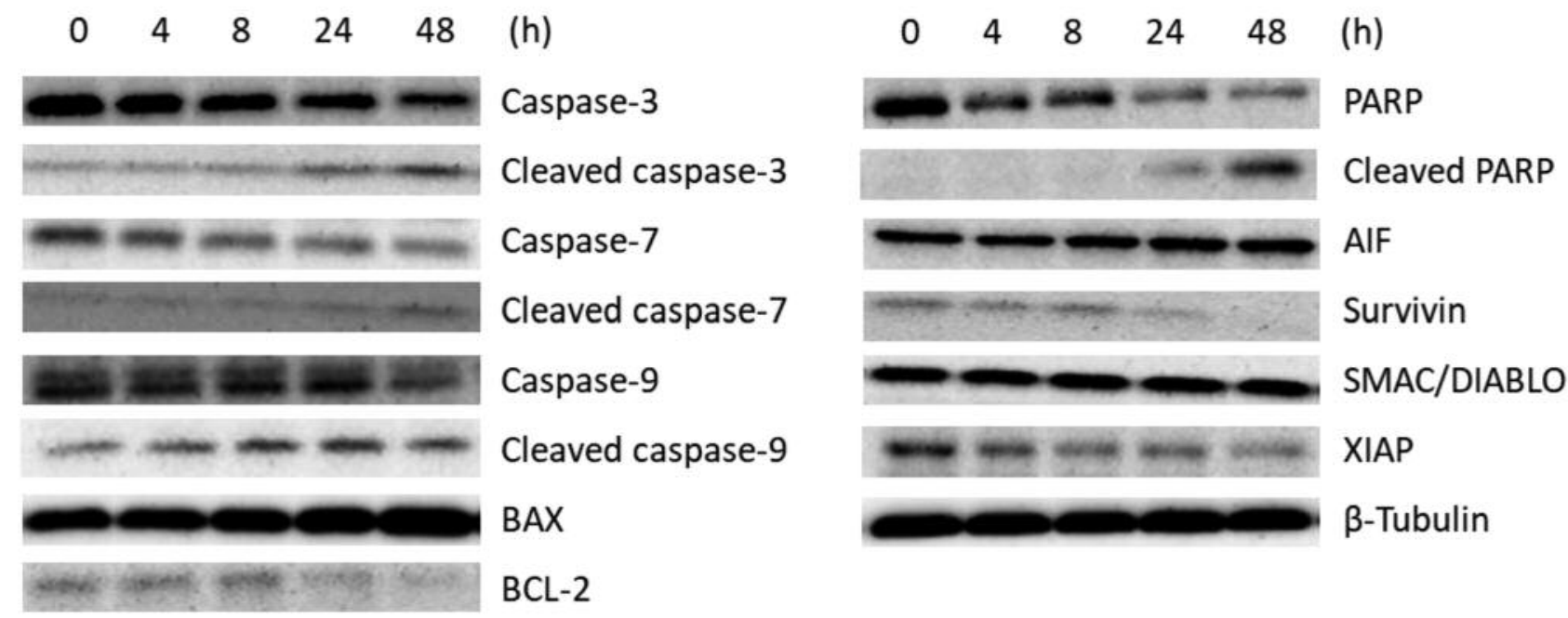

Figure 6. Western blot analysis for apoptosis-related proteins. NB-39 cells were treated with compound 4 (30 $\mu M$ ) for 0-48 h. The expression levels of apoptosis-related proteins were assessed by western blotting; $\beta$-tubulin was used as the loading control. BCL-2: B-Cell lymphoma 2 protein, BAX: BCL-2-associated X protein, AIF: poptosis-inducing factor, XIAP: X-linked inhibitor of apoptosis protein, PARP: poly (ADP-ribose) polymerase, SMAC/DIABLO: second mitochondria-derived activator of caspase/direct IAP-binding protein with low PI.

lines, with inhibitory concentration $\left(\mathrm{IC}_{50}\right)$ values for $\mathrm{LA}-\mathrm{N}-$ 1 and NB-39 of $49.67 \mu \mathrm{M}$ and $48.03 \mu \mathrm{M}$, respectively. Furthermore, the compound exhibited selective cytotoxicity against the neuroblastoma cell lines as compared to the two normal control cells (Figure 2).

To detect whether compound $\mathbf{4}$ induced apoptosis in neuroblastoma cells, we observed the cellular and nuclear morphological changes using Hoechst 33342 staining. Cell shrinkage, nuclear condensation and nuclear fragmentation, a feature of apoptosis, was observed in NB-39 cells treated with compound 4 (Figure 3, arrows at 30 and $100 \mu \mathrm{M}$ ): the severity of the apoptotic changes was found to be dose-dependent (Figure 3). Subsequently, the NB-39 cells treated with compound 4 were subjected to flow-cytometric analysis after annexin V-PI double staining (Figure 4). An increase in the percentage of early apoptotic cells was observed after treatment with the compound at $100 \mu \mathrm{M}$ (Figure 4, b4), and an increase in the percentage of late apoptotic cells was observed following treatment with the compound at $100 \mu \mathrm{M}$ (Figure 4, b2).

Inhibition of the caspase pathway was investigated using z-VAD-fmk, an irreversible, pan-caspase inhibitor. From the results, it was elucidated that $\mathrm{z}$-VAD-fmk significantly restored the survival rate of NB-39 cells treated with compound 4 (Figure 5).

We then examined the expression levels of caspasedependent apoptosis related proteins by SDS-PAGE and western blot analysis (Figure 6). Expression of caspase-3, 7 , and -9 decreased, while cleavage of the same caspases increased in a time-dependent manner. Subsequently,

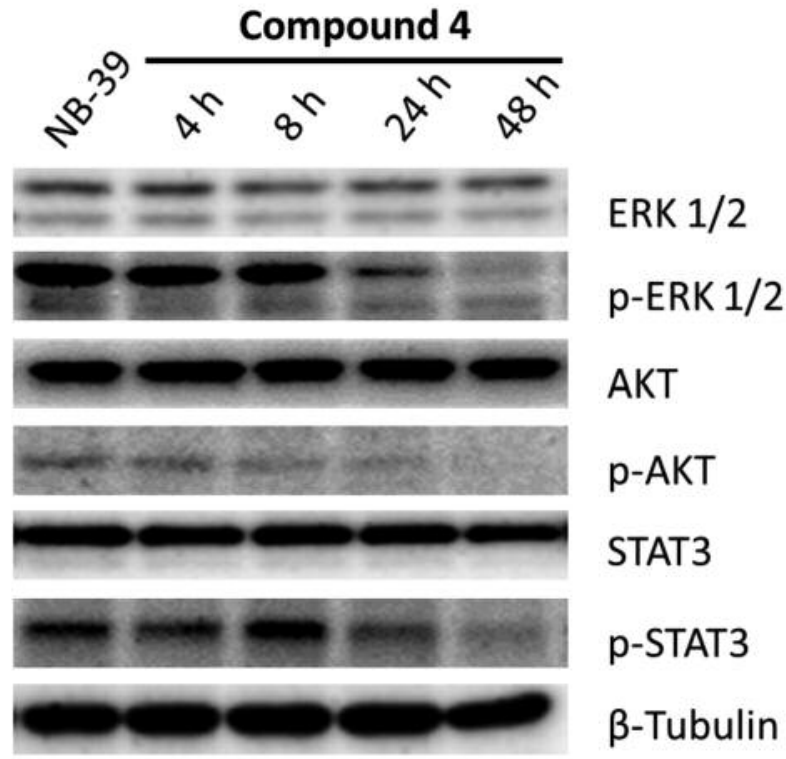

Figure 7. Western blot analysis for cell growth-related proteins. NB-39 cells were treated with compound $4(30 \mu \mathrm{M})$ for $0-48 \mathrm{~h}$. The expression levels of cell growth-related proteins were assessed by western blotting; $\beta$-tubulin was used as the loading control. ERK1/2: Extracellular signal-regulated kinase 1 and 2, AKT: AKT8 virus oncogene cellular homolog, STAT3:signal transducer and activator of transcription 3.

cleavage of PARP was detected. In addition, the protein level of BAX increased, and that of BCL-2 decreased slightly in a time-dependent manner. Moreover, the protein expression 
levels of survivin and XIAP decreased. We also examined the expression levels of cell growth-related proteins (Figure 7). Compound 4 significantly decreased the expression levels of phosphor-proteins relevant to cell growth pathways.

\section{Discussion}

In this study, we demonstrated cytotoxicity and apoptosisinducing cell death induced by burchellin derivatives in neuroblastoma cells. Compound $\mathbf{4}$ exhibited selective cytotoxicity against the neuroblastoma cell lines as compared to the normal control cells. Examination of the NB-39 cells by Hoechst 33342 staining after $24 \mathrm{~h}$ of exposure to compound 4 revealed features of cellular apoptosis, including cell shrinkage, nuclear condensation and nuclear fragmentation. In addition, annexin V-PI double staining also revealed an increase in the number of apoptosis cells. These results indicate that compound $\mathbf{4}$ induced apoptosis of NB-39 cells. In addition, the influence of caspases was examined in NB-39 cells treated with compound 4. The findings revealed that z-VAD-fmk significantly restored the survival rate, suggesting that compound 4 induces apoptosis via the caspase-dependent pathway. Caspases are known to play broad roles in apoptosis and inflammation. In the pathway of activation, the executioner caspases (caspase-3, -6, and -7), which are responsible for cell death, are cleaved and activated by the initiator caspases (caspase-8 and -9) (13). Caspase-8 mediates death receptormediated apoptosis (14) and caspase-9 triggers mitochondriamediated apoptosis (15), and both are involved in the activation of the executioner caspases. However, it has been reported that neuroblastomas do not express caspase- 8 , a key molecule in the extrinsic pathway of apoptosis, as a result of abnormal DNA methylation and allelic imbalance $(16,17)$. Accordingly, it may be presumed that apoptosis induced in NB-39 cells by compound 4 was mediated by caspase-3, -7 , and -9 .

We next examined the expression levels of apoptosisrelated protein. Expression of caspase-3, -7, and -9 decreased, while cleavage of the same caspases increased in a time-dependent manner. In addition, the protein level of BAX increased, and that of BCL-2 decreased slightly, in a time-dependent manner. While BAX can activate caspases and induce mitochondrial dysfunction, BCL-2 inhibits these processes (18). BAX induces activation of caspase-9, followed by activation of caspase-3, leading to apoptosis (19). Moreover, significant decreases in the expression levels of XIAP, and survivin, were observed following exposure to compound 4. Survivin is a member of the inhibitors of apoptosis protein (IAP) family, and plays an important role in the regulation of caspase-9 activation (20). Additionally, it is known that the anti-apoptotic role of survivin is mediated by its association with $\operatorname{XIAP}(20,21)$. These results indicate that compound $\mathbf{4}$ appears to induce mitochondrial pathway-mediated apoptosis. Furthermore, we also examined the expression levels of apoptosis-associated proteins. PARP is known to play a pivotal role in the response to DNA damage, inhibition of DNA repair and cell death, and it is cleaved by an effector caspase during apoptosis (22). In this study, we showed that compound $\mathbf{4}$ induced cleavage of PARP in a time-dependent manner. Therefore, we judged that compound $\mathbf{4}$ induces apoptosis of neuroblastoma cells via a caspase-dependent pathway.

The mitogen-activated protein kinase (MAPK) pathway encompasses various signaling cascades, of which ERK1/2 (23), the phosphoinositide 3 kinase-AKT pathway (24) and the Janus kinase (JAK)/STAT pathway $(25,26)$ regulate multiple critical cellular functions, including proliferation growth, senescence, differentiation, and apoptosis, in human cancer cells. Activation of growth factor signaling is seen in numerous malignant tumor cell lines. These pathways are being studied to identify novel therapeutic targets in neuroblastomas (27-29). ERK, AKT, and STAT3 influence $\mathrm{BAX}, \mathrm{BAD}$, and $\mathrm{BCL}-2$, factors regulating apoptosis mediated by the mitochondrial pathway $(25,30,31)$. These results indicate that compound $\mathbf{4}$ induces cell death through inhibition of the cell growth pathway. In addition, inhibition of cell growth factors by this compound may also affect the induction of apoptosis through caspase-9 activation.

In conclusion, we evaluated the antitumor effects of derivatives of burchellin contained in plants belonging to the Lauraceae family. We found that one of the burchellin derivatives (compound 4 ) exerted selective antitumor activity against neuroblastoma cells. Compound $\mathbf{4}$ induced caspasedependent apoptosis by a mechanism associated with the mitochondria pathway. In addition, our findings suggest the inhibition of cell growth factors (ERK, AKT, and STAT3) by compound $\mathbf{4}$ also played a role in the induction of apoptosis by this compound. These findings indicate that compound $\mathbf{4}$ may represent a lead compound for development of therapeutic drugs against neuroblastoma.

\section{Acknowledgments}

The Authors wish to thank Dr. Toshimitsu Suzuki, Fukushima Medical University School of Medicine, for providing the NB-39 cells. A joint research grant for this study was received from the School of Pharmacy, Nihon University (2013).

\section{References}

1 Maris JM, Hogarty MD, Bagatell R and Cohn S: Neuroblastoma. Lancet 369: 2106-2120, 2007.

2 Davidoff AM: Neuroblastoma. Semin Pediatr Surg 21: 2-14, 2012.

3 Mosse YP, Deyell RJ, Berthold F, Nagakawara A, Ambros PF, Monclair T, Cohn SL, Pearson AD, London WB and Matthay KK: Neuroblastoma in older children, adolescents and young adults: a report from the International Neuroblastoma Risk Group Project. Pediatr Blood Cancer 61: 627-635, 2014. 
4 Wagner LM and Danks MK: New therapeutic targets for the treatment of high-risk neuroblastoma. J Cell Biochem 107: 4657, 2009.

5 Lima OA, Gottlieb OR and Magalhaes MT: Burchellin, a neolignan from Aniba burchellii. Phytochemistry 11: 2031-2037, 1972.

6 Cabral MM, Azambuja P, Gottlieb OR, Kleffmann T, Garcia ES and Schaub GA: Burchellin: effect on Triatoma infestans and on Trypanosoma cruzi within this vector. Parasitol Res 87: 730-735, 2001.

7 Ribeiro AB, Bolzani VS, Yoshida M, Santos LS, Eberlin MN and Silva DHS: A new neolignan and antioxidant phenols from Nectandra grandiflora. J Braz Chem Soc 16: 526-530, 2005.

8 Narciso JO, Soares RO, Reis dos Santos Mallet J, Guimaraes AE, de Oliveira Chaves MC, Barbosa-Filho JM and Maleck M: Burchellin: study of bioactivity against Aedes aegypti. Parasit Vectors 7: 172-182, 2014.

9 Ma WW, Kozlowski JF and McLaughlin JL: Bioactive neolignans from Endlicheria dysodantha. J Nat Prod 54: 1153$1158,1991$.

10 Uchiyama T, Tabata K, Nomura S, Kaneko Y and Suzuki T: Induction of apoptosis in human leukemia cell (Jurkat) by neolignans isolated from seeds of Licaria puchury-major. Biol Pharm Bull 32: 1749-1753, 2009.

11 Hayama T, Tabata K, Uchiyama T, Fujimoto Y and Suzuki T: Ferrearin $\mathrm{C}$ induces apoptosis via hemo oxygenase-1 (HO-1) induction in neuroblastoma. J Nat Med 65: 431-439, 2011.

12 Engler TA, Wei DD, Letavic MA, Combrink KD and Reddy JP: Regioselective Lewis acid-directed reactions of 2-alkoxy-5alkyl-1,4-benzoquinones with styrenes: Synthesis of burchellin and guianin neolignans. J Org Chem 59: 6588-6599, 1994.

13 Mcllwain DR, Berger T and Mak TW: Caspase functions in cell death and disease. Cold Spring Harb Perspect Biol 5: a008656, 2013.

14 Peter ME and Krammer PH: The CD95 (APO-1/Fas) DISC and beyond. Cell Death Differ 10: 26-35, 2003.

15 Cain K, Brtton SB and Cohen GM: The APAF-1 apoptosome: a large caspase-acivating complex. Biochimie 84: 203-214, 2002.

16 Takita J, Yang HW, Chen YY, Hanada R, Yamamoto K, Teitz T, Kidd V and Hayashi Y: Allelic imbalance on chromosome 2q and alteration of the caspase- 8 gene in neuroblastoma. Oncogene 20: 4424-4432, 2001.

17 Teitz T, Lahti JM and Kidd VJ: Aggressive childhood neuroblastoma do not express caspase-8: an important component of programmed cell death. J Mol Med 79: 428-436, 2001.

18 Korsmeyer SJ: $B C L-2$ gene family and the regulation of programmed cell death. Cancer Res 59: 1693-1700, 1999.

19 Green DR and Reed JC: Mitochondria and apoptosis. Science 281: 1309-1312, 1998.
20 Mita AC, Mita MM, Nawrocki ST and Giles FJ: Survivin: key regulator of mitosis and apoptosis and novel target for cancer therapeutics. Clin Cancer Res 14: 5000-5005, 2008.

21 Dohi T, Okada K, Xia F, Wilford CE, Samuel T, Welsh K, Marusawa H, Zou H, Armstrong R, Matsuzawa S, Salvesen GS, Reed JC and Altieri DC: An IAP-IAP complex inhibits apoptosis. J Biol Chem 279: 34087-3490, 2004.

22 Soldani C and Scovassi AI: Poly (ADP-ribose) polymerase-1 cleavage during apoptosis: an update. Apoptosis 7: 321-328, 2002.

23 McCubrey JA, Steelman LS, Chappell WH, Abrams SL, Wong EW, Chang F, Lehmann B, Terrian DM, Milella M, Tafuri A, Stivala F, Libra M, Basecke J, Evangelisti C, Martelli AM and Franklin RA: Roles of the RAF/MEK/ERK pathway in cell growth, malignant transformation and drug resistance. Biochim Biophys Acta 1773: 1263-1284, 2007.

24 Osaki M, Oshimura M and Ito H: PI3K-AKT pathway: its function and alteration in human cancer. Apoptosis 9: 667-676, 2004.

$25 \mathrm{Yu} \mathrm{H}$, Pardoll D and Jove R: STATs in cancer inflammation and immunity: a leading role for STAT3. Nat Rev Cancer 9: 798809, 2009.

26 Zundler S and Neurath MF: Integrating immunologic signaling network: The JAK/STAT pathway in colitis and colitisassociated cancer. Vaccines 4: 4010005, 2016.

27 Tanaka T, Higashi M, Kimura K, Wakao J, Fumino S, Iehara T, Sakai $\mathrm{T}$ and Tajiri $\mathrm{T}$ : MEK inhibitors as a novel therapy for neuroblastoma: Their in vitro effects and predicting their efficacy. J Pediatr Surg 51: 2074-2079, 2016.

28 King D, Yeomanson D and Bryant HE: PI3King the lock: targeting the PI3K/Akt/m TOR pathway as a novel therapeutic strategy in neuroblastoma. J Pediatr Hematol Oncol 37: 245-251, 2015.

29 Yan S, Li Z and Thiele CJ: Inhibition of STAT3 with orally active JAK inhibitor, AZD1480, decreases tumor growth in neuroblastoma and pediatric sarcomas in vitro and in vivo. Oncotarget 4: 433-445, 2013.

30 Datta SR, Brunet A and Greenberg ME: Cellular survival: a play in three Akts. Genes Dev 13: 2905-2927, 1999.

$31 \mathrm{Lu} \mathrm{Z}$ and $\mathrm{Xu} \mathrm{S}$ : ERK 1/2 MAP kinases in cell survival and apoptosis. IUBMB Life 58: 621-631, 2006.

Received November 17, 2017

Revised December 4, 2017

Accepted December 8, 2017 